\title{
Analysis Competitiveness And Exchange Rate Effect On Indonesian Terms Of Trade 1995-2016
}

\author{
Francisca Sestri Goestjahjanti \\ STIE Insan Pembangunan \\ e-mail: sestri.rahardjo@gmail.com
}

\begin{abstract}
The purpose of this research is to discuss and review the influence of competitiveness and exchange rates to Indonesian term of trade. The problem of this research is how the influence of competitiveness and exchange rate variable simultaneously and partially to Indonesian term of trade. This research used secondary data time series for 22 years since 1995 to 2016. The research method used explanatory research to explain the causal relationship between the variables in a model, through hypothesis testing. The analysis employed statistical technique of linear regression with the software SPSS -22 and E-views-7. The results of the researches showed that these variables competitiveness and exchange rate are simultaneously and partially give positive and significant effect on Indonesian term of trade.
\end{abstract}

Key words: competitiveness, exchange rate, term of trade.

\section{INTRODUCTION}

ASEAN agreed to rely on the cooperation of intra district, so between fellow members they compete. But they acknowledge the regional economic activity, less excited lately because it suffered on various economic and political issues in various parts of the world, as reported by CNN news agencies (CNN, 2016).

Some sentiment become highlight in ASEAN Finance Minister's Investors Forum, in the 11th Seminar on 15 November 2016 in Jakarta, among others the impact of China's economic stagnation, as well as the appearance of the United Kingdom from the European Union (Britain Exit) known by the term Brexit, up to Donald Trump's victory in the presidential election, the United States under his leadership made the new tension between the United States with North Korea about the nuclear weapons issue is getting warmed up. A follow-up meeting of the ASEAN Ministerial on July 4 to 8 August 2017 in Manila, threatened to fail due to the strength of the hegemony of China claims most of the waters of the South China Sea are their own, it is because of softening attitude of the Philippines against China does this harm the interests of Malaysia, Brunei and Viet Nam. In the future solidities and wholeness of ASEAN could be questioned.

Circumstances led to the revised world economic growth is declining. In the end it will affect foreign trade policies against each country's particular economic region of ASEAN. Indonesia developing country has the largest population in the ASEAN region.

The Ministry of Internal Affairs data showed a total population of Indonesia reached two hundred and fifty-seven million more by mid-June 2016. (Tribune news.com, 2016). Indonesia's rich natural resources and human resources, it will be tempting the export of objects of any country, and this is a risk to become a member of WTO, as the World Trade Organization facilitates international trade affairs since the publication of law No. 7 Year 
1994 on "ratification of International trade agreements Establishing The Organization World Trade". The era of globalization involving the World Trade Organization (WTO) that each Member State is required to have the competitiveness at the global level, so that the goal of international trade can be realized with the utilization of open markets, to increase the value of exchange rate with expectation of export value is always higher than the value of imports.

Without an increase in the competitiveness of the economy, through core variables are difficult performance exports to compete with other parties.

Free trade will be opportunities in the competitiveness of a country that is does the exchange value is high. In fact it is precisely the question of Indonesia's competitiveness that becoming a classic problem of stagnated reflected its rank (M. Chatib Basri et. al, 2012)

According to the reference (M. Kertajaya, 2012), the structural adjustment program by the IMF (International Monetary Fund) in the global economy may not apply in poorer countries. This condition will be getting worse when running the more privatization and free trade that has been demonstrated empirically in Africa.

The other facts in the ASEAN market shows that the ASEAN Free Trade Area like Singapore at first rank, as presented in the following table.

Table 1. The Competitiveness of The ASEAN Country Year 2010 - 2016

\begin{tabular}{lllll}
\hline Years & Malaysia & Singapore & Thailand & Indonesia \\
\hline 2010 & 26 & 3 & 38 & 44 \\
2011 & 21 & 2 & 39 & 46 \\
2012 & 25 & 2 & 38 & 40 \\
2013 & 24 & 2 & 37 & 38 \\
2014 & 24 & 2 & 31 & 38 \\
2015 & 20 & 1 & 28 & 34 \\
2016 & 25 & 2 & 34 & 41 \\
\hline
\end{tabular}

Source: World Bank and WEF (2016)

The table shows in 2016, competitiveness in all ASEAN countries are experiencing a decline include Indonesia from 34 percent to 41 percent rating, it decreased 20.5 per cent. The exchange rate of rupiah against foreign currencies in the international trading is very influential for importing and exporting activities. The higher value of the currency of the exporting country, become a threat to importing countries, since it should provide higher costs. Indonesia's one country that is largely determined by its supply of raw materials, material capital from abroad.

According to Indonesian chambers of Commerce and Industrynotes that $70 \%$ of industrial raw materials, capital goods and food consumption of the community are still imported (Indonesian Chambers of Commerce and Industry, 2013). Identified that the stability of the exchange rate of the rupiah is very dependent from foreign policy especially the United States, evident since the election of Donald Trump as President of the United States on March 9, 2016, the Asian market sentiment still in progress. On the 11th of November 2016, rupiah exchange rates be USD $1=$ IDR, 1,389 closed and rupiah exchange rate getting lower 1.95 percent compare to the previous days. 
The terms of trade is export price index comparison with their import price index, a measure of the success of a country to market their goods abroad. Indonesia has a very fluctuating exchange rate basis and in the last few years has decreased, due to the decreasing of oil prices in the world and a dropping of commodity prices of certain goods that became the mainstay of Indonesia's exports destinations.

Competitiveness and the exchange rate of the rupiah against the dollar is a United States independent variables will be examined as determinants of Indonesian terms of trade. In the future the Indonesian terms of trade is expected to increase from year to year so-unable to retrieve employment, as well as improving the welfare of Indonesian societies.

Formulation Of The Problem. Based on the description above, then the introduction in this study can be formulated: How is the simultaneous and partial influence between the competitiveness and the exchange rate variables against the Indonesian terms of trade?

Research Objectives. Referring to the outline of the above problem formulate, then the purpose of the study was defined as follows: to discuss and assess the influence simultaneously and partially of the competitiveness and exchange rate variables against Indonesian terms of trade.

The Global Economy. Scientific research always starts from a wide variety of writing research results both in the form of books, literature or previous scientific journals, and refers to a grand theory as the foundation of his scientific writing. This study refers to international economic theory is a marketing of local product to international markets.

International Economic Theory. International Economics is part of Economics discusses the special issues through trade transactions among nations or country (Masngudi, 2013). According to among others (Sukirno, 2012) free trade is a system of foreign trade where each country doing trade with no barriers to trade.

The terms of trade. One of the indicators measuring the success and benefit of the exchange of goods and services through international trade terms of trade is the size (base rates) between exports and imports. The basis of this import export rate can affect the level of prosperity of a nation and at the same time as a means of measuring the position of the nation's foreign trade (Nopirin, 2012). Various measurement terms of trade:

1) Net better terms of trade. It is the ratio between export price index to import price index.

2) Gross barter terms of trade. It is the ratio of the volume of exports against the import volume.

3) Income terms of trade. That increase income of a country can import a greater based on the value of its export. This means that these countries get the trust of other countries who are doing trade transactions International.

4) Double factorial terms of trade. There are two formulation that is single and double

Competitiveness. The competitiveness of a country is high indicating success of the country contributed the peoples, reflected on the payment of taxes, social contributions, sponsorship son activities of benefit to the community. The sense of competitiveness are able to develop their performance and ability to better compete in the future of a country that performs the exchange of products, the form of the sale of goods and services in international markets. The question of the competitiveness of the domestic economy on pertained to the classic from the first till now the issue is business as usual. Economic 
institution in developing countries cannot be compared to the best practices in the developed countries (M. Chatib Basri.Et al, 2012). Some of the variables that affect the competitiveness are adapted from Source the Global Competitiveness Reporting the World Economic Forum are: basic requirement, institution, infrastructure, macro-economic environment, health.

Exchange Rate. Masngudi (2013) he said exchange of rupiah against foreign currencies, namely the international payment system is expressed in the form of a currency of a country with the currency of other countries. Mentioned to the export and import activities this exchange rate determines how the value of the exports of goods of a country against the value of their import. While (Sukirno, 2012) foreign exchange rate stated, indicating the price or value of a country's currency expressed in the currencies of other countries. There are two ways to determine the foreign exchange rate:

1) Upon request and supply of foreign currency in a free market. This more flexible system because the system can accommodate currency transactions of very great value

2) The government determined. Each country will maintain reserves in gold, United States dollars or in other currencies are strong, to maintain the stability of the value of its currency Government can intervene in determining the exchange rate of foreign currency, in order to ensure a tangible exchange rate does not cause adverse effects to the economy.

\section{The relevant of earlier research}

Table 2. The list of earlier research

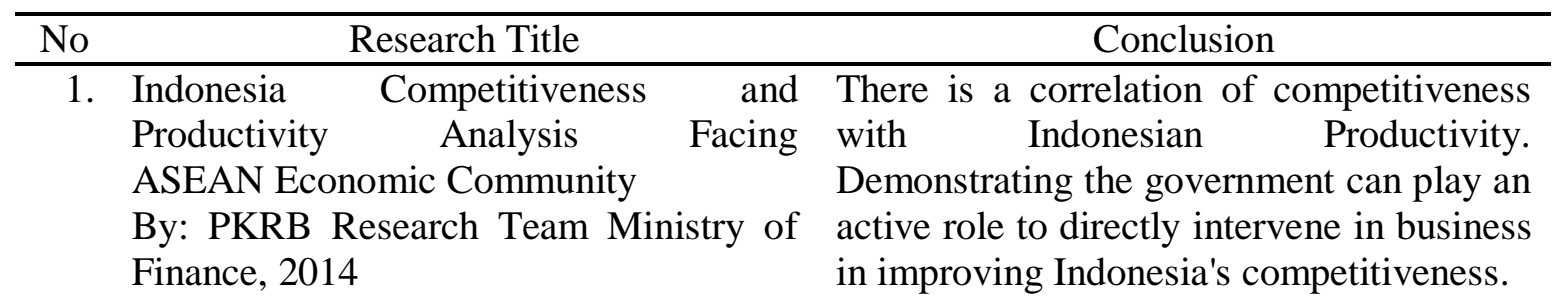

2. The Effect of Exchange Rates on 1) Long-term exchange rates have a Indonesian Exports

By: Ari M. Gintin, 2013 negative and significant impact on Indonesian exports.

2) Short-term exchange rates have a negative and significant impact on Indonesian exports.

3) Indonesian exports have a positive trend

3. The Influence of Import Exports In The development of imported exports is International Trade To The Economy In the determining factor of the economy in Indonesia Indonesia By: Yuni Yulianingsih. 2014.

4. Impact of the European Economic Crisis Against Indonesia's Export and Import Development By: Riska Ayu Pramono, et. al. 2013.

1) GDP factors, exchange rates, and imported export values affect the economic slowdown in Indonesia.

2) The European Economic Crisis had an impact on Indonesia's exports, in 2009 decreased USD. $116,510.00$ 


\section{e}

5. Analysis of Effect of Loan interest rate and exchange rate against non-oil exports Riau province 2001- 2013. By: Sulaiman, et.al. 2014.

7. Effect of Inflation and exchange rate against Indonesian Export Commodities Textiles and Electronics South Korea before and after the implementation of AKFTA

By: Ray. Fani Arining Princess et. al. 2016.

8. Impact analysis Rupiah exchange rate on non-oil and gas exports in Indonesia By: Hafizah, Rasyid. 2016. equivalent14.97 percent

1) Loan interest rate and exchange rate simultaneously influence the Riau province ranked non-oil exports 2001 2013.

2) Loan interest rates have a negative and significant effect on non-oil and gas export of Riau Province from 2001 to 2013.

3) Exchange rate positively affects nonoil export of Riau Province 2001 2013

1) Simultaneously Inflation and Exchange rate effect on export value ASEAN-5.

2) Partially exchange rate depreciation negatively affects the export of ASEAN countries minus the Philippines.

3) Partially inflation has positive effect only in the Philippines

Inflation and exchange rate did not significantly affect Indonesia Commodity exports of textiles to South Korea, before and after the implementation of AKFTA in 2011

1) Short term money supply M2 has significant effect on non-oil and gas exports in Indonesia,

2) Short-term money supply M2 significant effect on non-oil exports in Indonesia.

9. Analysis of factors affecting the Domestic Production Export Woodwork in the District of Gianyar, Ubud District. By: FitriaIdayanti. 2016

10. The effect of Supply Chain Management Against Corporate Performance and Competitive Advantage (A Case Study of Creative Industry in Central Java). By: Lisda Rahmasari. 2011.
1) Labor factor, Capital, Investment have a positive effect on Domestic Wood Craft Production in Gianyar, Ubud District.

2) The availability of raw materials has a negative and significant effect on the export of domestic production of Wood Craft Kec. Ubud Kab. Gianya.

1) Supply Chain Management Practices have a positive and significant impact on Kenggulan Bersaing.

2) Supply Chain Management Practices have a positive and significant impact on Corporate Performance.

3) Competitive Advantage has a positive and significant impact on Company 
11. Examining the Effect of Currency Depreciation on Trade Balance in Selected Asian Economics.

By: Alemu, Aye Mengistu and Jin- Sang, Lee. 2014

12. Assessing The Competitiveness of Malaysia and Indonesia Palm Oil Related Industry.

By: M. Affandy Arip, Lau Sim Yee and Theen Sie Feng. 2013
Performance.

1) This study found no evidence for the effect of depreciation to improve trade of balance of about 14 Asian economies. This was perhaps due to the fact that export did not respond as expected, mainly due a decline in terms of trade for primary commodities and manufactures products or due heavy dependence on import goods which maybe more expensive in the local currency.

2) The number of countries under study into 8 countries that are relative bigger, that depreciation improved trade balance.

1) The Revealed Comparative Advantage (RCA) indexes for these products is in both countries are unstable during the analytical period.

2) Malaysia is more competitive than Indonesia is most of the downstream Palm Oil Industries such S3-42229, S3-42249, S3-43122, S3-52222 and S3-55419.

3) As the Biggest producers of Palm Oil both countries should put more emphasis on downstream Industrial products which are of higher valueadded-taking the benefit of their comparative advantage in upstream industries

\section{CONCEPTUAL FRAMEWORK}

The conceptual framework of this research model, is the relationship between the independent variables Competitiveness and Exchange rate to the dependent variable Indonesian terms of trade is as follows:

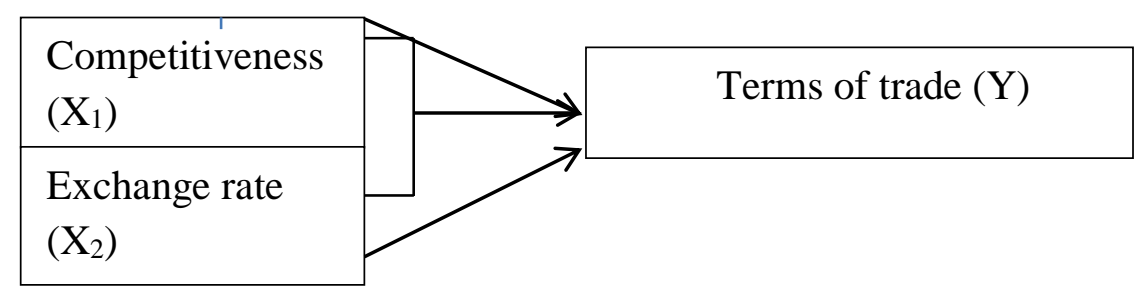

Figure 1. Conceptual Framework

$\mathrm{X}_{1}$ : Competitiveness is independent variable. 
$\mathrm{X}_{2}$ : Exchange rate is independent variable.

$\mathrm{Y}:$ Terms of trade is dependent variable.

Hypothesis. The hypothesis in this study, referring to opinion of (BurhanBungin, 2013) hypotheses a conclusion that has not been perfect, so it needs to be refined by proving the hypothesis's truth.This research put forward hypothesis as follows: 1). There are significant and simultaneous positive and significant influencebetweencompetitiveness and exchange rate variables on Indonesian terms of trade 2). There is a positive and significant influence between competitiveness variable to theIndonesian terms of trade 3). There is a positive and significant influence between the variable of the Exchange rate to the Indonesian terms of rate

\section{METHODS}

Research methods in this paper include research design, variable measurement and analysis techniques.

Design Research. Quantitative research design used include research title, problem background, problem formulation, research objective, usefulness of concept boundary research, determination of indicator variable, research hypothesis, measurement, data source, research $\mathrm{m}$ The implementation of this research is conducted in the Territory of Indonesia.

Secondary data types from Bank Indonesia, BPS, World Bank, WEF and method. The research design is ultimately an all-needed process in planning and conducting research. The type of time series data for 22 years. The time required of the study began data collection, data processing and research results report, for 4 (four) months starting from August 2017 until November 2017.

Population And Sample. Population in this research is all data of competitiveness, exchange rate and base value of Indonesia's import export. The sample in this study is the same as the population. The sampling technique was carried out by taking all the secondary data from the study population for 22 years with observation. Based on the description of problem formulation, research objectives, and frameworks until the research hypothesis. So the research method in this writing is explanatory research (explanatory research) that is research using hypothesis testing between variables that have a causal relationship in a model (Burhan Bungin, 2013).

Analysis Method. Correlation Test. How to analyze the relation of independent variable with dependent variable.

Determination Coefficient Test. These parameters indicate the magnitude of the influence of independent variables to the dependent variable.

Regression Test. Regression analysis studies the relationship between one or more independent variables $\left(\mathrm{X}_{1}, \mathrm{X}_{2}, \ldots \mathrm{Xn}\right)$ with one independent variable $(\mathrm{Y})$ in a model. 


\section{RESULTS AND DISCUSSION}

Description of Research Objects. This research covers the processing, discussion of secondary data concerning competitiveness factors, exchange rate of rupiah to United States dollar, which allegedly has a big and significant influence on the value of Indonesian terms of trade, which is very important in the free trade era. The data of variables studied for the period 1995 to 2016.

The results and discussion of Model $1, \mathrm{Y}=\mathrm{f}\left(\mathrm{X}_{1}, \mathrm{X}_{2}\right)$. Statistical analysis using SPSS Version 22, addressed the results as follows:

Table 3. Multiple Linear Regression X1, X2 against $Y$

Model Summary

\begin{tabular}{llllllr}
\hline Model & $\mathrm{R}$ & R Square & Adjusted R Square & $\begin{array}{l}\text { Std. Error of } \\
\text { Estimate }\end{array}$ & \\
\hline 1 &, $885^{\mathrm{a}}$ &, 783 &, 760 &, 06135 & \\
\hline
\end{tabular}

a. Predictors: (Constant), VAR 2 Kurs, VAR 1 DayaSaing

\section{Correlation test}

Table 4. Correlation $\mathrm{X}_{1}, \mathrm{X}_{2}, \mathrm{Y}$

Correlations

\begin{tabular}{lllll}
\hline & & V1 D Saing & V2 Kurs & V3 DasarTukar \\
\hline VAR1 D Saing & Pearson Correlation & 1 &, $514^{*}$ &, $783^{* *}$ \\
& Sig. (2-tailed) & &, 015 &, 000 \\
& $\mathrm{~N}$ & 22 & 22 & 22 \\
VAR2 Kurs & Pearson Correlation &, $514^{*}$ & 1 &, $756^{* *}$ \\
& Sig. (2-tailed) &, 015 & &, 000 \\
VAR3 & $\mathrm{N}$ & 22 & 22 & 22 \\
DasarTukarEkp & Pearson Correlation &, $783^{* *}$ &, $756^{* *}$ & 1 \\
orImpor & Sig. (2-tailed) &, 000 &, 000 & \\
\hline
\end{tabular}

*. Correlation is significant at the 0.05 level (2-tailed).

**. Correlation is significant at the 0.01 level (2-tailed).

Multiple Correlation Test. Referring to table 3, the correlation test between $\mathrm{X}_{1}$ and $\mathrm{X}_{2}$ to $\mathrm{Y}$, yields a number of $\mathrm{R}=0,885$ which indicates a close, positive and very strong relationship

Simple Correlation Test. Referring to table 3, a simple correlation test of $\mathrm{X}_{1}$ to $\mathrm{Y}$, yields a number of $\mathrm{R}=0.783$ which shows a very strong positive relationship. The correlation test of $\mathrm{X}_{2}$ to $\mathrm{Y}$, yields a number of $\mathrm{R}=0.756$ indicating a strong and positive relationship.

Determination Coefficient Test. The result of determination test shows the coefficient of determination (R2).From the analysis of table 3, obtained the number $(\mathrm{R} 2)=0.783$, it means the magnitude of the influence between exchange rate variables $\left(\mathrm{X}_{1}\right)$ and competitiveness $\left(\mathrm{X}_{2}\right)$ simultaneously against Indonesian terms of trade $(\mathrm{Y})=78.30$ percent, and 21, 70 percent influenced by other variables in outside model. 


\section{Regression Test}

Table 5. Equation of regression $\mathrm{Y}=\mathrm{f}\left(\mathrm{X}_{1}, \mathrm{X}_{2}\right)$

\begin{tabular}{|c|c|c|c|c|c|c|}
\hline \multicolumn{7}{|c|}{ Coefficients $^{\mathrm{a}}$} \\
\hline & & $\begin{array}{l}\text { Unstar } \\
\text { Coeffi }\end{array}$ & lized & $\begin{array}{l}\text { Standardized } \\
\text { Coefficients }\end{array}$ & & \\
\hline \multicolumn{2}{|c|}{ Model } & $\mathrm{B}$ & Std. Error & Beta & $\mathrm{T}$ & Sig. \\
\hline \multirow[t]{3}{*}{1} & (Constant) & 2,776 & ,262 & & 10,601 &, 000 \\
\hline & VAR 1 Competitiveness & ,224 & 052 & ,537 & 4,310 & ,000 \\
\hline & VAR 2 Exchange Rate & ,128 & 033 & ,480 & 3,854 & 001 \\
\hline
\end{tabular}

a. Dependent Variable: VAR 3 Terms of trade

Regression model $\mathrm{Y}=\mathrm{a}+\mathrm{b}_{1} \mathrm{X}_{1}+\mathrm{b}_{2} \mathrm{X}_{2}+\varepsilon$

$\mathrm{Y}=$ Terms of trade; a =Constant; $\mathrm{X}_{1}=$ Exchange rate; $\mathrm{X}_{2}=$ Competitiveness;

$\varepsilon=$ Standard error.

$$
\mathrm{Y}^{\wedge}=\mathbf{2 , 7 7 6}+\mathbf{0 , 2 2 4} \mathrm{X}_{1}+\mathbf{0 , 1 2 8} \mathrm{X}_{2}
$$

Referring to table 5, the regression equation shows the effect of positive, constante value $(\mathrm{C})$, competitiveness $\left(\mathrm{X}_{1}\right)$, and exchange rate $\left(\mathrm{X}_{2}\right)$ as compared to Indonesian terms of trade changed $\left(\mathrm{Y}^{\wedge}\right)$.

The interpretation of the regression model is, if the variables $\left(X_{1}\right),\left(X_{2}\right)$ are 0 , then the value of $\mathrm{Y}^{\wedge}$ will change to 2,766 as the constant. If the value of the constant and, $\left(\mathrm{X}_{2}\right)=0$ then $\left(\mathrm{Y}^{\wedge}\right)$ will change to $0.224 *\left(\mathrm{X}_{1}\right)$, if the constant and $\left(\mathrm{X}_{1}\right)=0$, then $\left(\mathrm{Y}^{\wedge}\right)$ will change to $0.128 *\left(\mathrm{X}_{2}\right)$, assumsion another variable is ceteris paribus.

\section{F Test}

Table 6. Level of Significance $X_{1}, X_{2}$ toY

\begin{tabular}{lllllll}
\multicolumn{8}{c}{ ANOVA $^{\mathbf{a}}$} \\
\hline Model & & Sum of Squares & Df & Mean Square & F & Sig. \\
\hline 1 & Regression &, 258 & 2 &, 129 & 34,280 &, $000^{\mathrm{b}}$ \\
& Residual &, 072 & 19 &, 004 & & \\
& Total &, 330 & 21 & & & \\
\hline
\end{tabular}

a. Dependent Variable: VAR 3 Terms of Trade

b. Predictors: (Constant), VAR 2 Exchange rate, VAR 1 Competitiveness

Referring to table $6, \mathrm{~F}$ test is found the result as bellow:

1) $\mathrm{F}$-count $=34.280, \mathrm{n}=22, \mathrm{k}=2, \alpha=0,05$, then $\mathrm{F}$ table $=3,440$.

2) $\mathrm{F}$ count $>\mathrm{F}$ table And Sig Test. $=0,000<\mathrm{p}$ value $\alpha=0,05$ then Significant. Then the hypothesis of model 1 , Ho is rejected and Ha accepted, that is simultaneously there is a positive influence, significant between competitiveness variable $\left(\mathrm{X}_{1}\right)$ and exchange rate $\left(\mathrm{X}_{2}\right)$ on Indonesian terms of trade $(\mathrm{Y})$.

\section{Analysis and Discussion Model 2, $Y=\mathbf{f}\left(\mathbf{X}_{1}\right)$}

Statistical analysis using SPSS version 22, the following results: 
Table7. The effect of $\mathrm{X}_{1}$ on $\mathrm{Y}$

\begin{tabular}{llllll}
\hline \multicolumn{7}{c}{ Model Summary } \\
Model & $\mathrm{R}$ & $\mathrm{R}$ Square & Adjusted R Square & $\begin{array}{l}\text { Std. Error } \\
\text { Estimate }\end{array}$ \\
\hline 1 &, $783^{\mathrm{a}}$ &, 613 &, 594 &, 07982 \\
\hline
\end{tabular}

a. Predictors: (Constant), VAR 1 Competitiveness

Correlation Test. Simple Correlation Test. Referring to table 7, a simple correlation test $\mathrm{X}_{1}$ to $\mathrm{Y}$, the result of $\mathrm{R}=0.783$ which indicates the strong and positive relationship.

Determination Coefficient Test. Referring to table 7 , the result coefficient of determination $\left(R^{2}\right)=0.613$, the magnitude of influence between variables Competitiveness $\left(\mathrm{X}_{1}\right)$ partially on Indonesian terms of trade $(\mathrm{Y})=61.30 \%$ and $38.70 \%$ remaining influenced by other variables in outside model.

\section{Regression test}

Table 8. Equation of Regression $\mathrm{Y}=\mathrm{f}\left(\mathrm{X}_{1}\right)$

\begin{tabular}{lllllll}
\multicolumn{8}{c}{ Coefficients $^{\mathbf{a}}$} \\
\hline \multirow{2}{*}{ Model } & & \multicolumn{2}{l}{$\begin{array}{l}\text { Unstandardized } \\
\text { Coefficients }\end{array}$} & $\begin{array}{l}\text { Standardized } \\
\text { Coefficients }\end{array}$ & \\
\cline { 2 - 5 } & B & Std. Error & Beta & t & Sig. \\
\hline 1 & $\begin{array}{l}\text { (Constant) } \\
\text { VAR }\end{array}$ & 3,545 &, 221 & & 16,052 &, 000 \\
& $\begin{array}{l}\text { Competitive } \\
\text { ness }\end{array}$ &, 326 &, 058 &, 783 & 5,633 &, 000 \\
\hline
\end{tabular}

a. Dependent Variable: VAR 3 Indonesian terms of trade

$\mathrm{Y}=\mathrm{a}+\mathrm{b}_{1} \mathrm{X}_{1}+\varepsilon$

$\mathrm{Y}=$ Terms of trade; $\mathrm{a}=$ Constant $\mathrm{X}_{1}=$ Exchange rate; $\varepsilon=$ Standard error

$$
Y^{\wedge}=3,545+0.326 X_{1}
$$

Referring to table 9, the above regression equation indicates a positive influence between the constants $(\mathrm{C})$, the change of competitiveness $\left(\mathrm{X}_{1}\right)$ on the change of Indonesian Term of Trade $\left(\mathrm{Y}^{\wedge}\right)$.

Interpretation of the regression model is, if $\mathrm{X}_{1}$ is 0 , then the value will be changed to $\mathrm{Y}^{\wedge}=$ 3.545 as per constants. If the value of constant is 0 , then $\left(\mathrm{Y}^{\wedge}\right)$ will be changed to $0.326 \mathrm{x}$ $\left(\mathrm{X}_{1}\right)$, assuming another variable is ceteris paribus.

t - Test (partial test). Referring to table 8, the simple linear regression hypothesis test and the significance test as follows:

1) $\mathrm{t}$-count $=5,633, \mathrm{n}=22, \mathrm{k}=1, \alpha=0,05$, value $\mathrm{t}$-two tilled $\mathrm{t}$ table $(\mathrm{n}-\mathrm{k}-1)=1,721$.

2) $\mathrm{t}$-count $>\mathrm{t}$ table And Test Sig. $=0,000<\mathrm{p}$ value $\alpha=0.05$ significant results.

3) The model hypothesis 2 , Ho is rejected and Ha accepted, that is partially there is a positive influence, significant between competitiveness variable $\left(\mathrm{X}_{1}\right)$ on Indonesian terms of trade $(\mathrm{Y})$. 
The results and Discussion of Model 3, $Y=f\left(X_{2}\right)$

Statistical analysis using SPSS version 22, the following results:

Table 9. Coefficient of Determination $\mathrm{X}_{2}$ on $\mathrm{Y}$

Model Summary

\begin{tabular}{llllll}
\hline & & & & Std. Error of the \\
Model & $\mathrm{R}$ & R Square & Adjusted R Square & Estimate & \\
\hline 1 &, $756^{\mathrm{a}}$ &, 571 &, 549 &, 08409 & \\
\hline a. Predictors: (Constant), VAR 2 Kurs & & & \\
Coefficient of Determination $\left(\mathrm{R}^{2}\right)$ & &
\end{tabular}

Simple Correlation Test. Referring to table 10, a simple correlation test of $\mathrm{X}_{2}$ to $\mathrm{Y}$, the result of $\mathrm{R}=0.756$ which indicates the strong and positive relationship.

Determination Coefficient Test. Referring to table 10, the determination coefficient of $\mathrm{R} 2$ is obtained $=0,571$, meaning that the influence between the variables of exchange rate (X2) partially to Indonesian terms of trade $(\mathrm{Y})=57.10 \%$ and $42.90 \%$ is influenced by other variables in outside model.

Table 10. Regression of Equation $\mathrm{Y}=\mathrm{f}\left(\mathrm{X}_{2}\right)$

\section{Coefficients $^{\mathrm{a}}$}

\begin{tabular}{lllllll}
\hline & & \multicolumn{3}{c}{ Standardized } \\
Model & & \multicolumn{2}{c}{ Unstandardized Coefficients } & Coefficients & & \\
\cline { 2 - 4 } & & B & Std. Error & Beta & t & Sig. \\
\hline 1 & (Constant) & 2,961 &, 354 & & 8,361 &, 000 \\
& VAR 2 Kurs &, 202 &, 039 &, 756 & 5,158 &, 000 \\
\hline
\end{tabular}

a. Dependent Variable: VAR 3 DasarTukarEkporImpor

$\mathbf{Y}=\mathbf{a}+\mathbf{b}_{2} \mathbf{X}_{2}+\boldsymbol{\varepsilon}$

$\mathrm{Y}=$ Term of Trade; $\mathrm{a}=$ Constants $; \mathrm{X}_{2}=$ Exchange rate; $\varepsilon=$ Standard error

$$
Y^{\wedge}=2,961+0,202 X_{2}
$$

Referring to table 10, the above regression equation indicates a positive influence between the constants $(\mathrm{C})$ value, the change of exchange rate $\left(\mathrm{X}_{2}\right)$ on Indonesian Term of Trade $\left(\mathrm{Y}^{\wedge}\right)$, so it has a direct relationship. Interpretation of the regression model is, if $\mathrm{X}_{2}$ is $=0$, then the value will be changed to $\mathrm{Y}^{\wedge}=2.961$ for constants. If the value of constant is 0 , then $\mathrm{Y}^{\wedge}$ will change to $0.202 *\left(\mathrm{X}_{2}\right)$

T-Test (Partial Test). Referring to table 11, then test the simple regression hypothesis and test significance as follows:

1) $\mathrm{t}$-count $=5,158, \mathrm{n}=21, \mathrm{k}=1, \alpha=0,05$, nilsi $\mathrm{t}$ two tilled t table $(\mathrm{n}-\mathrm{k}-1)=1,721$.

2) $\mathrm{t}$-count $>\mathrm{t}$ table And Test Sig. $=0,000<\mathrm{p}$ value $\alpha=0,05$ then Significant.

3) Then the hypothesis of model 3 , Ho is rejected and Ha accepted, that is partially there is a positive influence, significant between the variables Exchange (X2) on the basis of imported Indonesian export (Y). 


\section{CONCLUSIONS AND SUGGESTIONS}

Conclusions. Based on secondary data and analytical results as well as the discussion that has been described above, this study can be summarized as follows: (1) Simultaneously there is a positive influence, very strong relationship and significant between competitiveness and exchange rate on Indonesian terms of trade; (2) There is a positive influence, strong relationship and significant between competitiveness on Indonesian terms of trade; (3) There is a positive influence, strong relationship and significant between exchange rate variables on Indonesian terms of trade.

Suggestions. Based on the conclusion of the above mentioned this research, it is suggested that the following things:

1) The Government in this case the Ministry of Trade, the Ministry of Industry and the Coordinating Minister for the Economy is expected to issue a justice regulation to encourage the growth of investment in industry, trade in export destination, so that Indonesian term of trade will increase.

2) National investors must use a technology-based for online business, with efficient and effective so that Indonesia's competitiveness will stronger in the international market.

3) It takes synchronization between Central Bank of Indonesia (macro policy) and the Financial Services Authority (micro policy of industry, trade in goods and services), through the supervision and control ofthe exchange rate against foreign currency, in order to create stability considering about $70 \%$ of raw materials, domestic industrial capital is imported.

\section{REFERENCES}

Alemu, Aye Mengistu and Jin-Sang Lee. (2014). "Examining The Effects of Currency Depreciation On Trade Balance in Silected Asian Economics" International Journal of Global Business. 7 (1) 59-76. Seoul, South Korea.

Amilia H. Salsabila and Kertahadi.Et. al. (2015). "The Influence of Foreign Direct Investment (FDI) and Competitiveness to Exports (Study in Indonesia Manufacturing Industry Sector 2004-2013)". Journal of Business Administration (JAB).Vol. 2.No. 2 Faculty of Business Administration.Brawijaya University.

BambangBrojonegoro. (2013). "Support and Synergy of Inter-Ministerial Policy in the National Industrial Development Stage" Focus Group Discussion.Indonesian Chambers of Commerce and Indusrtryin Jakarta.

Bungin, Burhan, (2013). Social and Economic Research Methodology of Quantitative and Qualitative Formats. Jakarta, Indonesia: KencanaPrenada Media Group.

CNN.(2016). Focus Discussion of ASEAN Finance Ministers forum, Intra-Regional Economy. (Retrifide from: www.cnn.com / 17-7-2017)

Central Bank of Indonesia.(2016) Rupiah Exchange Rate, Import Export Code, www.BI.go.id.World Bank.(2016) State competitiveness.www.worldbank.com.

Central Bureau of Statistics, (2016)."Exchange", www.BPS.go.id.

FitriaIdayanti (2016). "Analysis of Domestic Production Factors Affecting WksporKerajianKayu In Ubud District of Gianyar Regency". E-Journal of Development Economics, 5 (1), .FEB.Udayana University. Indonesia.

Ginting and Ari.M. (2013)."The Effect of Exchange Rate on Indonesian Exports". Journal of Center for Assessment of Information Data of DPR-RI Jakarta, Indonesia. 
Hafizah, Rashid. (2016). “Analysis of the Impact of Rupiah Exchange Rate on Non Oiland Gas Exports in Indonesia". Diploma of Thesis Faculty of Economics AndalasUniversity.Indonesia.

LisdaRahmasari. (2011) "The Effect of Supply Chain Management Against Company Performance and Competitive Excellence (Case Study in Creative Industries of Central Java) "Journal of Informatics Magazine, 2 (3), .AKI University.Indonesia.

Masngudi. (2013). International Economy Continued, Jakarta, Indonesia: Textbook, Faculty of Economics, University of Borobudur.

M.ChatibBasri, et al. (2012) Home Economy Culture House. Jakarta, Indonesia: PT. GramediaPustakaUtama.

M.Kertajaya. (2012).The Economic Inspiration That Changed the World. Yogyakarta, Indonesia: Pinus Book Publisher.

M.AffandyArip and Lau Sim Yee.et.al. (2013) "Assesing the Competitiveness of Malaysia and Indonesia Palm Oil Related Industry". World Review of Business Research Journal. 3 (4), 138-145. Malaysia.

MuhamadFuad Ansari and AdibElkalia.et. al. (2017). "Influence Analysis of Inflation and Exchange Rate on Export Value in ASEAN-5 Country Period Year 2012 - 2016". Journal Pknstan INFO ARTHA, 1, (2). ISSN (e-ISSN): 2581-0839 New.

Nopirin. (2013) International Economy.BPFE Universitas Gajah Mada.Yogyakarta, Indonesia

Pranoto and RiskaAyu.et.al. (2013). "Impact of the European Economic Crisis Against the Development of Indonesia's Export Import". Journal of Lecturer Scientific Works, FE University of Riau, Indonesia.

Ray. Fani Arining Putridan Suhadak. et.al. (2013). "Inflation Influence And Exchange Rate Against Indonesian Exports of South Korea's Textile and Electronic Commodities" Journal of Business Administration (JAB). 35 (1). Faculty of Business Administration, UniversitasBrawijaya, Indonesia.

Sulayman and Grace Richard.Et. al. (2014). "Analysis of Influence of Credit Interest Rate and Exchange Rate to Non Oil and Gas Exports of Riau Province". JOM FEKON Journal. 1 (2.) University of Riau, Indonesia.

PKRB Research Team. (2014). Analysis of Competitiveness and Productivity of Indonesia in ASEAN Economic Area. Ministry Finance, Jakarta.

Tribune Central Java.(2016) Population of Indonesia. (Retried from http://jateng.tribunnews.com/2016/09/01/data-terkini-jumlah-penduduk-ndonesia-/ 17-7-2017)

WEF. (2016) ASEAN country competitiveness. (Retried from www.wei.dayasaingasean2016 / 17-7-2017)

Yulianingsih, Yuni. (2014). "The Effect of Export Import In Trading International for Indonesia's Economy Depok City ".Thesis of Scientific Work of Faculty of Economics, Gunadarma University. 